INTERNATIONAL JOURNAL FOR

HISTORY, CULTURE AND MODERNITY

www.history-culture-modernity.org

Published by: Uopen Journals

Copyright: @ The Author(s).

Content is licensed under a Creative Commons Attribution 4.0 International Licence

elSSN: 2213-0624

\title{
Global Counter-Enlightenment: Introductory remarks
}

Matthijs Lok and Joris van Eijnatten

HCM 7: 406-422

DOI: $10.18352 / \mathrm{hcm} .563$

\begin{abstract}
Although there is little historical evidence for a clear-cut dichotomy between Enlightenment and Counter-Enlightenment as two coherent and unchanging traditions, it still makes sense to talk about Enlightened as well as Counter-Enlightened currents in modern thought. Much of the extant literature has been devoted to the Counter-Enlightenment's European context. We now draw attention to the global dimensions of Counter-Enlightened thought. Did a 'Counter-Enlightened international' exist? Can we draw parallels between manifestations of a Counter-Enlightenment in different parts of the world?
\end{abstract}

Keywords: Counter-Enlightenment, global history, Isaiah Berlin, transnationalism

\section{Return of a Global (Counter-) Enlightenment?}

In a sense, putting Counter-Enlightenment on the agenda again is the result of disillusionment. During the two decades following the fall of the Berlin wall, it seemed that an enlightened era of indefinite duration had begun. History seemed to have come to an end. A new cosmopolitan way of life, a global capitalist economy and a digital society appeared to sum up the future of the world, and that of Europe in particular. The old nation states were fading out, to be replaced soon by less homogeneous, multileveled forms of government and civic identity. The post-national European Union with its hybrid constitution and undefined borders was 
bound to become the model of all new political entities to emerge in the new globalized world. ${ }^{I}$ Intellectuals such as Jürgen Habermas looked towards the eighteenth-century Enlightenment as a foundational era that mirrored contemporary world citizenship. ${ }^{2}$ And although critics blamed the Enlightenment for evils ranging from colonialism and racism to narrow-minded Eurocentrism, its supporters regarded the eighteenth century as the golden age of cosmopolitanism, preceding the rise of intolerant, exclusivist national identities in the wake of the French Revolution. ${ }^{3}$

The new era did not, of course, materialize, at least not in the way many people at the time expected or hoped. But the Enlightenment scholarship of those years reflected the post-I989 globalization of the economy, society and culture. While the I980s had underscored the plural, national character of the European Enlightenments, in the I990s and 2000 s the focus of Enlightenment studies became increasingly global. ${ }^{4}$ To be sure, in 2012 Sebastian Conrad, in a well-known essay, still argued for a more global and less Eurocentric approach to the Enlightenment. In his view 'the standard interpretations ... have tended to assume, and to perpetuate, a Eurocentric mythology. They have helped entrench a view of global interactions as having essentially been energized by Europe alone.'5 'Historians', he continued, 'have now begun to challenge this view. A global history perspective is emerging in the literature that moves beyond the obsession with the Enlightenment's European origins ... Enlightenment ideas need to be understood as a response to cross border interaction and global integration. ${ }^{6}$ Intellectual historians have likewise followed the call for a more global and less Eurocentric approach to the study of the Enlightenment. ${ }^{7}$

Since the turn of the millennium the cultural climate seems (at least for the moment) to have become less receptive to the idea and ideals of cosmopolitan citizenship. The 9/I I attacks shattered the notion of a self-evident 'end of history' and raised the spectre of a world determined, not by a united nations, but by a 'clash of cultures'. The economic crisis of 2008 ushered in a new wave of nationalism in the West, from Donald Trump's ascent to power in the U.S. and the emergence of the Brexit in Britain to the rise of populism in Western Europe and the growth of 'illiberal democracies' in Central and Eastern Europe. Not just the EU and the U.S. had witnessed the revival of national pride and attacks on liberal and cosmopolitan politicians and institutions; 
similar developments took place in Turkey, Russia, Brazil, India and elsewhere.

In his passionate appeal to a less Eurocentric and more globally inclusive approach, Conrad paid little attention to the need to study the eighteenth-century critics of the Enlightenment, in Europe and beyond. ${ }^{8}$ This applied to most of the new global intellectual historians. Giving due attention to the transfer of ideas, 'interconnections' and mobilities, they focused mostly on those historical actors who defended and propagated the Enlightened ideals, rather than on those who opposed them; they studied the history of equality, not that of inequality. ${ }^{9}$ The global dimension of the self-proclaimed 'enemies of the Enlightenment', as well as the conservative opponents of progressive ideals, has remained surprisingly understudied.

One of the exceptions to the rule was Pankaj Mishra, who interpreted what he regarded as an 'Age of Anger' from a long-term perspective by examining the Western intellectual tradition since Rousseau. ${ }^{\mathrm{IO}}$ Following Ian Buruma's Occidentalism, Pankaj found the origins of the hatred of Western liberal modernity in the European intellectual tradition itself. ${ }^{\text {I }}$ Rousseau was one the first to criticize Enlightened society as decadent and superficial, extolling 'primitive' purity instead. Herder and the German Romantics, Mishra claimed, formulated a powerful alternative to Enlightened universalism by highlighting the differences between national cultures. In his rather diffusionist view, Enlightenment criticism subsequently spread around the world to influence Islamic, Russian, Chinese, Japanese and Indian political philosophies, on which the later widespread aversion to liberal, Western-style modernity would draw.

Mishra was neither the first nor the last to blame current attacks on Western liberalism on a counter-Enlightenment, anti-revolutionary tradition rooted in eighteenth-century Europe. Recently Jan Zielonka has drawn attention to the current 'counter-revolution' against the liberal revolution of I989, seeing it as a repetition of the counter-revolutionary opposition of $1789 .{ }^{12}$ In his view, twenty first-century anti-liberalism parallels eighteenth and nineteenth-century conservative hostility to the Enlightened, liberal heritage. In a much criticized book, Zeev Sternhell had earlier traced a continuous anti-liberal tradition from the eighteenth century, through National Socialism and fascism, to present-day right-wing movements. 'The great enemies of the Enlightenment were 
not mistaken', Sternhall writes, 'it is enough to compare the view of man of Rousseau, Voltaire, Fontenelle, and Lessing with that of Burke, Herder, Taine, de Maistre and Spengler to see the gulf that existed between the Enlightenment and its enemies.' ${ }^{\text {I3 }}$

Although these books should perhaps be regarded as contributions to a political debate, rather than as purely scholarly studies, they do raise interesting questions. If a 'Global Enlightenment' existed, to what extent can we speak of a 'Global Counter-Enlightenment'? Does the criticism, in different parts of the globe, of a modern world allegedly created by the secular Enlightenment, reveal crossovers and commonalities? Can we employ a diffusionist model, as Mishra seems to imply, with a flow of ideas over time from Europe to other parts of the world? Our aim is to make a start with exploring the different historical manifestations of 'Counter-Enlightenment' in different parts of the world. To maintain some coherence, we have asked scholars to reflect in particular on the way French eighteenth-century philosophie was received in different regions. We are interested in the meaning of contested concepts such as 'Enlightenment' and 'Counter-Enlightenment' (and their linguistic equivalents) in different contexts, focusing on intellectual pedigrees rather than cultural attitudes or emotional responses. Can we discern a circulation of counter-Enlightened ideas on a global scale? Or, to phrase our main concern differently: can we speak of the CounterEnlightenment as a global phenomenon?

\section{Defining the 'Counter-Enlightenment'}

As Darrin McMahon points out in his contribution, the notions of 'Enlightenment' and 'Counter-Enlightenment' are not neutral; they are inherently ambiguous ideas. ${ }^{14}$ Both 'Enlightenment' and 'CounterEnlightenment' are value-laden concepts and tend to be studied on the basis of specific agendas. This applies especially, but certainly not exclusively, to the older works. Biographies of eighteenth-century critics of the Enlightenment were often hagiographies written by authors who stood in the same religious tradition to which their protagonists had belonged. ${ }^{15}$ Likewise, progressive historians of the I960s and I970s, like the highly influential Peter Gay, hardly paid attention to the religiously inspired critics of the philosophes, regarding them as unsympathetic people who wrote from the wrong side of history. ${ }^{16}$ 
Since the I980s scholars have become increasingly interested in the religious dimension of the Enlightenment, discarding the myth of a purely secular philosophie, or even a 'pagan' one, as Gay would have it. However, on the whole scholars of the so-called 'religious Enlightenment' have been more interested in moderate thinkers who strove to fuse Enlightenment and revealed religion than in those who declared themselves explicitly to be 'enemies' of the Enlightenment. ${ }^{17}$ Robert Roswell Palmer's Catholics and Unbelievers in Eighteenth Century France, published in 1939 under the shadow of World War II and the rise of fascism, can be regarded as an early example of a more detached study of the critics of the Enlightenment in eighteenth-century France. Rather than depicting apologetes of the Catholic Church as mere reactionaries, Palmer underscored their willingness to adapt the ideas and methods of the Enlightenment to further their own agendas, for instance by using new historical methodologies to support church doctrine and the truth of biblical events. ${ }^{18}$

The work of philosopher Isaiah Berlin (I909-1997), who as a child fled the Russian Revolution and emigrated to Britain, was of fundamental importance to the study of the Counter-Enlightenment in the post-war decades. Berlin viewed the monism and universalism of (French) Enlightenment thought as the main cause for the development of twentieth-century totalitarianism. 'The central doctrines of the progressive French thinkers, whatever their disagreements among themselves, rested on the belief, rooted in the ancient doctrine of natural law, that human nature was the same in all times and places'. ${ }^{19}$ In contradistinction to Enlightenment universalism, Berlin identified a range of thinkers who in his view supported pluralism and the incommensurability of values; these included Giambattista Vico (I668-I 774), Johann Gottfried von Herder (I744-I803), Johann Georg Hamann (I730I788) and Joseph de Maistre (I753-I82I). According to Berlin, this Counter-Enlightenment consisted of a 'family of political and moral conceptions ... based on the defiant rejection of the central thesis of the Enlightenment, according to which what is true, or right, or good, or beautiful, can be shown to be valid for all men by the correct interpretation of objective methods of discovery and interpretation, open to anyone to use and verify. ${ }^{20}$

Much of Berlin's interpretation has now been discredited. Critics found little historical evidence for what they called Berlin's essentialist dichotomy between Enlightenment and Counter-Enlightenment as two 
coherent and unchanging traditions. ${ }^{21}$ The Catholic Maistre would have been horrified to learn that he had been lumped together with Herder, an author he regarded as a Spinozist and an atheist. The presumed liberal character of the antiphilosophes' thought has also been questioned. Mark Lilla described Vico as a conservative and 'anti-modern' figure who defended organized religion and hierarchical authority. ${ }^{22}$ Jeffrey Burson drew attention to religious polarization within the eighteenthcentury French church itself. ${ }^{23}$ Carolina Armenteros, among others, criticized the interpretation of Maistre as a 'reactionary with a medieval mindset', or a modern proto-fascist. Instead she placed him in the tradition of a moderate Catholic Enlightenment, stressing (too much, perhaps) the many similarities between Maistre's historical thought and that of the philosophes, and the utopian socialist legacy of his ideas. ${ }^{24}$

Around the turn of the millennium, two books with similar titles appeared, both avoiding an essentialist definition of CounterEnlightenment: Didier Masseau's Les ennemis des philosophes (2000) and Darrin McMahon's Enemies of the Enlightenment of 200I. ${ }^{25}$ In his book on the French antiphilosophes Masseau described how the selfdeclared 'enemies of the Enlightenment' adopted the strategies and literary forms of their opponents, forming a veritable counter-enlightened 'public sphere'. Like Masseau, but in contrast to Berlin, McMahon took a historical approach:

\begin{abstract}
Rather than begin on high, with an abstract definition of what Enlightenment entailed, I begin on the ground, examining what hostile contemporaries themselves said about the siècle des lumières and its actuating principle, philosophie. As we shall see, it was over and against their own construction of their enemies' doctrines - a construction, that is, of the Enlightenment that the men and women in this study positioned themselves in direct Counter-Enlightenment opposition. ${ }^{26}$
\end{abstract}

Again in contrast to Berlin, McMahon did not just study a handful of well-known philosophers, but examined lesser known thinkers, including journalists and theologians. While Masseau highlighted the rupture the French Revolution brought about among the antiphilosophes, McMahon emphasized the continuity of Counter-Enlightenment thought from the last decades of the eighteenth century to the early nineteenth-century Restoration. The French Revolution proved the truth 
of the antiphilosophes' warning that Enlightened ideas would eventually lead to the destruction of the civil and political order. Some of their work was reissued in the I820s, as part of the campaign to reposition the Catholic Church.

McMahon and Masseau primarily studied antiphilosophie within its French national context. At the same time, McMahon pointed to the global effects of the French antiphilosophes. Their books were read all over Europe, both in Catholic and Protestant countries, as well as in the Portuguese and Spanish-speaking Americas. ${ }^{27}$ Translated into a range of languages, French antiphilosophe writings were adapted to local and national audiences. ${ }^{28}$ Even in countries that had experienced the Enlightenment only marginally an antiphilosophe tradition could be found. McMahon did not extensively discuss this so-called 'CounterEnlightenment international'. This special issue aims to fill part of this void.

A telling example of transnational Counter-Enlightenment was the work of Francois-Xavier de Feller (I735-I802), a Jesuit from the southern Netherlands turned journalist. Feller travelled widely and was connected to a large international network of correspondents, many of them former Jesuits. In his Journal Historique et Litteraire, published between I773 and I794, he discussed Latin and French scholarly works from all over Europe, doing so from a Counter-Enlightenment perspective, in terms of an apocalyptic battle between the forces of religion and atheism. He gave his opinion on current affairs and international politics, fiercely condemning the American and French revolutions as rebellions motivated by atheism and anarchy. He regarded the Belgian Revolution against the Habsburg Emperor Joseph II as a defence of traditional freedoms against the centralizing policies of an Enlightened despot. His geographical and historical dictionaries used the wellknown Enlightenment format to defend church hierarchy and revealed religion. A deeply religious author, Feller was both a cosmopolitan who wrote antiphilosophe travel literature and a self-styled patriot who defended local and regional independence vis-à-vis foreign overlords. ${ }^{29}$

Perhaps a word on the relationship between 'Counter-Enlightenment' and 'Conservatism' is in order, since these two (contested) concepts are often related in public debates as well as in scholarly literature. On the one hand, a certain family resemblance can be observed. The case of Feller shows that the confident antiphilosophes of the I770s and I780s 
became the counter-revolutionaries of the I790s, seeing the Revolution as the fulfilment of their apprehension concerning the Enlightenment. These antipathies spilled over into nineteenth-century conservatism, as did other Counter-Enlightenment hobbyhorses, such as the value of traditional religion, the distaste for abstract ideas and the defence of social hierarchy and inequality. Karl Mannheim had already observed this in the I930s; he mentioned such characteristics as a predilection for the concrete, a qualified idea of freedom, the assumption of a preestablished harmony, a tension between liberty and order and a spatially rooted understanding of history. ${ }^{30}$ But there are also clear differences. There is an important European tradition of so-called 'Enlightened conservatives', one well-known representative of which is Edmund Burke, who criticized the French Revolution from the perspective of what could be called a position of Enlightenment reform. According to these Enlightened conservatives, the revolutionaries had undone the progress made over the previous decades by replacing moderate and lawful government with radical and despotic atheism and anarchy, and destroying both a centuries-old civilization and a tradition of political and civil freedom..$^{31}$ The case of Maistre demonstrates that counterrevolutionaries could also be radical, and even revolutionary, in their proposals for a reformed and regenerated society. ${ }^{32}$

\section{Global Counter-Enlightenment and Modernity}

There is no denying that historical actors like Feller and Maistre were opposed to what we would now identify as the eighteenth-century Enlightenment. For want of a better term, we can call them CounterEnlightened. Thinkers such as these made adroit use of Enlightenment formats and often pushed for social and political reform. Despite their sometimes blunt, seemingly anti-modern stance, many opponents of the Enlightenment were in many ways undeniably modern in any mainstream meaning of the word. At the very least, they had to relate to 'modernity' in the broadest sense, whether as a breach in time (symbolized by the revolutions they witnessed), novel institutions (such as the restoration governments after I8I5) or new technologies (opponents of the Enlightenment usually made adroit use of media). The modernity advocated by the philosophes may have held the future, but it has never 
been the only available option, neither in Europe nor beyond. ${ }^{33}$ CounterEnlightenment, then, is not necessarily the same as anti-modernity, as studies on the Enlightenment have often implied, nor is it confined to the Age of the Enlightenment stricto sensu (which is difficult to define anyway).

There are, of course, examples of what we could call unadulterated anti-modern, anti-reformist Counter-Enlightenment, by virtue of a reactionary rejection of the spirit of the times and a point-blank refusal to enter into meaningful public debate. One very curious manifestation of Enlightenment opposition in Britain were the so-called Hutchinsonians, an elite group of thinkers within the Church of England who were adamantly opposed to anything that reeked even slightly of Deism. This in itself does not qualify them as either Counter-Enlightened or antimodern. What does make them eligible is their stridently Trinitarian theology, which included a highly idiosyncratic linguistic method that firmly anchored the Trinity in both the New and Old Testaments and a no less esoteric Trinitarian cosmology they considered to be a necessary antidote to Newtonianism. Initially developed by John Hutchinson (I674-I737), Hutchinsonian thinking was so far beyond the pale of even orthodox theology that the movement, once its adherents started to update their ideas (that is, to modernize them), simply dissolved through assimilation. ${ }^{34}$

Religious sects such as the Hutchinsonians can easily be diagnosed as both Counter-Enlightened and anti-modern: a whole spectrum of intellectual and spiritual mavericks from late seventeenth-century Spinozist sects to socially isolated churches in the present amply illustrates this. ${ }^{35}$ Of course, in such cases the question often arises what, exactly, the baseline for modernity is, since many sects in the West have their roots primarily in the nineteenth and early twentieth centuries, and are thus paradoxically modern in spite of their professed anti-modernity. Presumably the term 'sect' itself is unhappily chosen, because much of what went on in the realm of 'belief', ranging from Christian orthodoxy to occultism, was supported by bona fide members of mainstream society, driven by modernity in any plausible sense but at the same time constructing their own particular 'counter public spheres' ${ }^{36}$

Mainstream adherents to Counter-Enlightened ideas, however, could not and cannot afford to be reactionary or unambiguously anti-modern if they wanted to have any impact on society. They strove to adapt society 
to meet contemporary requirements (that is, they wanted to modernize) but at the same time they employed norms and values and principles that often implied exactly the opposite of what 'right-thinking' social majorities would have accepted as a matter of course. In other words, multiple modernities are not just divided temporally and spatially over countries and continents, as research since the I990s has made abundantly clear; intellectually, too, modernity is inherently multiple. It comes in different blends, including Enlightened, non-Enlightened and Counter-Enlightened currents. Of course, this does not mean that all envisaged modernities are viable, and we can certainly ask to what extent the Counter-Enlightened versions are, despite the attraction they have had, and still have, in and beyond Europe.

Yet, two major Counter-Enlightenment themes, nationalism and religion, are still at play in the world today, while the currently growing gap between the rich and the rest smacks of old-fashioned inequality and hierarchy. Since its inception in the decades around I80o modern nationalism has come in different flavours, ranging from left-wing liberal to right-wing populist. The 'irrational' appeal to the 'traditional' values of volk and fatherland, whose antecedents are usually lost in the mists of time, and therefore need to be invented, reinvented, or both, has not lost its charm. Meanwhile, religion is almost infinitely adaptable to any form of modernity; there is little that modern religious people have found unable to believe, once committed to a belief, regardless of whether they considered themselves radically or moderately Enlightened, or not Enlightened at all. Again, this is not to say that Counter-Enlightened thinkers could not be cosmopolitan (a Catholic like Maistre regarded himself as a member of a religious international), or that they were necessarily religious.

The question is not really one about viability, intellectual or otherwise, but about the fact that Counter-Enlightened modernities existed. For as a powerful current closely interwoven with modernity, mainstream 'Counter-Enlightenment' was and is bound to arise wherever 'Enlightenment' made or makes headway. This implies in turn that if it is impossible to speak of a single global Enlightenment then obviously any attempt to regard the Counter-Enlightenment as even remotely something supra-local or supra-regional, let alone coherent, must also fail ignominiously. The rejection of the Enlightenment's universal appeal is not new: the literature reflects the argument in two ways. One 
strand we might call 'post-modern'. Postmodernity was never enamoured of the Enlightenment, seeking to consign it to the particularist province of dead, white, European males, and perhaps a smattering of dead white females, who all sought knowingly or unknowingly to conceal a rather vulgar discourse on power in the language of universal rationality. The postmodern approach is, of course, fundamentally linguistic, and it is not by accident that that the second form of particularism emerges from the disciplinary domain of language and literature. Hamad and Woltering, in their article on 'Télémaque, Tahțāwī and the (Counter-) Enlightenment in the Arab world', offer a mild version of this argument. ${ }^{37}$ They raise intriguing questions:

do ideas perceived as part of opposite thought movements in Europe necessarily carry the same perception elsewhere? Is it likely that a thinker whose geographical, religious, political and cultural context vastly differs from that of the epicentre of a philosophical movement, will be familiar with the complex nuances of that movement? If not, then can he be seriously considered a proponent of that movement? We would answer all of these in the negative.

The point here is that translation and reception are contextual practically by definition. To ensure the understanding of a set of ideas in an environment that is not just geographically and culturally, but often also temporally far removed from the context in which those ideas originally arose, means that these ideas need to be changed, that is, to be reinterpreted, re-evaluated and otherwise refashioned, sometimes beyond recognition. And even if the ideas remain close to what the initial author had 'intended' (intention in itself is an insurmountably problematic notion, according to some), there is nothing that warrants that ideas, once translated, will then be received, processed and reformulated by new audiences in a manner that more or less resembles the archetypes.

The paradox is that the denial of the universal purchase of ideas, whether on the basis of an ideological position (as in postmodernism), detailed empiricism (as in translation studies) or both, itself comes down to a Counter-Enlightenment position. But such arguments lead to fruitless sophistry. Instead, we suggest a return to, or rather a revision of, Isaiah Berlin, of the idea of the Counter-Enlightenment as a reasoned 
opposition to universal, rational, 'Enlightened' values, by those 'critics of secularism and liberalism who mourn the loss of faith, of collective unities, and of "values"'; critics who, like Herder and Hamann, resent the "loneliness" brought about by modern society and its mechanistic and rational-utilitarian ways' and seek solace and redemption in religion, folk-rootedness and nationalism ${ }^{38}$ in their many nineteenth and twentieth-century manifestations - and who have done so within, as well as far beyond, France, Europe and the West.

This brings us back to the idea of multiple modernities. If such modernities exist, then so, too, do counter-modernities; and even if, in the wake of postcolonial criticism, 'the' Enlightenment must be associated exclusively with French, European or Western society, global opposition to 'westernization' can in this respect fairly be called Counter-Enlightened. Given the enormous global impact of European colonialism and imperialism before World War II, this take on a global Counter-Enlightenment is hardly implausible. It easily allows comparisons between Herder and Hamann and leading non-European but often Western-trained intellectuals, whether or not the latter had actually read (or in some cases even heard of) the former. Thinkers like the Hindu Rabindranath Tagore (I86I-I94I), the Muslim Muhammad Iqbal (I877-I938) and the Confucian Liang Shuming (I893-I988) all opposed the dual axis of modernity-Westernization in resoundingly Counter-Enlightened terms. They saw Western, Enlightened modernity as an assault on tradition and 'Eastern' values, and as the advocacy of instrumental reason in the service of materialist consumption and brutal exploitation. ${ }^{39}$

The Enlightened, liberal, progressive modernity so widely applauded as the way upwards and forwards had failed to deliver; it could never deliver because it was unable to meet the deepest spiritual needs and time-tested values of mankind, the principles, tenets, customs and ethical precepts embedded in age-old civilizations, as those of Christianity once were fixed firmly in the West. As Adam Webb points out, such conservative, reformist writers are perfectly comparable to Thomas Stearns Eliot (a conservative convert to 'Anglo-Catholicism') in Britain, José Ortega y Gasset (whose critique of 'modern civilization' has conservative overtones) in Spain, José Enrique Rodó (who balanced his anti-Americanist rejection of nordomanía with an appeal to Spanish-American values) in Uruguay, and the twelve intellectuals and poets who in I930 authored I'll Take My Stand: The South and the Agrarian Tradition (in which they 
countered the dehumanizing urbanism imposed by the morally corrupt, industrialized North). And so on, and so forth.

Despite the many pitfalls, we believe it possible to trace a global counter-Enlightenment across space, time and culture, as long as the apposite caveats and warnings are given. This is not to say that simplistic diffusionist explanations obtain, or that the enemies of the Enlightenment all originate in the West. It is merely to say that the history of ideas is a complex affair and that transnational history should be written with care. Sometimes ideas will get lost completely in translation; more often, we suspect, they will not. The reason we think that there is substance to the claim of a global Counter-Enlightenment actually existing in different times and places is threefold. First, since the eighteenth century the world has been an increasingly networked world, so that ideas of all sorts were intelligently exchanged and no less intelligently received, although there could well be a large time lapse between the one and the other. Second, modernity and reform may have been multiple but they were multiple in concert, so that it would be parochial and short-sighted to overlook commonalities in and across different places and periods. Third, the Enlightenment, modernity, cosmopolitanism, globalization, 'Americanization', and so on, are intricately and complicatedly interrelated phenomena which have always elicited resistance, both popular and intellectual. They still do; there is no escaping Counter-Enlightenment.

\section{Notes}

I F. Fukuyama, The End of History and the Last Man (London, I992); T.L. Friedman, The World is Flat. The Globalized World in the Twenty-First Century (London, 2005).

2 G. Delanty, The Cosmopolitan Imagination. The Renewal of Critical Social Theory (Cambridge, 2009).

3 M.C. Jacob, Strangers Nowhere in the World. The Rise of Cosmopolitanism in Early Modern Europe (Philadelphia, 2016). L. Hunt, Inventing Human Rights: A History (New York, 2007).

4 R. Porter, The Enlightenment (Basingstoke, 200I).

5 S. Conrad, 'Enlightenment in Global History: A Historiographical Critique', American Historical Review I I7/4 (2012), 999-I027. 
6 Conrad, 'Enlightenment', 999.

7 S. Moyn and A. Sartori (eds), Global Intellectual History (New York, 20I3). Also Christopher L. Hill, National History and the World of Nations: Capital, State, and the Rhetoric of History in Japan, France, and the United States (Durham N.C., 2008); Andrew Sartori, Bengal in Global Concept History: Culturalism in the Age of Capital (Chicago, 2008).

8 Jonathan Israel's studies on the Enlightenment provide much information on the self-proclaimed enemies of the philosophes. Israel basically shares the antiphilosophes' view of the Enlightenment as secular, homogeneous and revolutionary, although in contrast to them he interprets this positively. Among others J. Israel, Radical Enlightenment. Philosophy and the Making of Modernity, I650-I750 (Oxford, 200I).

9 For instance S. Stuurman, The Invention of Humanity. Equality and Cultural Difference in World History (Boston, 2017).

Io P. Mishra, Age of Anger. A History of the Present (New York, 2017).

I I I. Buruma and A. Margalit, Occcidentalism: The West in the Eyes of Its Enemies (London, 2004).

I2 J. Zielonka, Counter-Revolution. Liberal Europe in Retreat (Oxford, 20 I8).

I3 Z. Sternhell, The Anti-Enlightenment Tradition (New Haven, 20I0). Sternhell, Anti-Enlightenment Tradition, 428.

I 4 D.M. McMahon, 'What is Counter-Enlightenment?', International Journal for History, Culture and Modernity, 5 (2017), 33-46; DOI: http://doi. org/IO. I 8352/hcm.508.

I5 M. Riquet, Augustin Barruel. Un Jésuite face aux Jacobins francs-maçons I74I-I820 (Paris, I989).

I6 P. Gay, The Enlightenment I: The Rise of Modern Paganism (2 volumes; New York, I966).

I7 D. van Kley, The Religious Origins of the French Revolution from Calvin to the Civil Constitution, I560-I79I (New Haven, I996); D. Sorkin, The Religious Enlightenment. Protestants, Jews and Catholics from London to Vienna (Princeton, 2008).

I8 R.R. Palmer, Catholics and Unbelievers in Eighteenth century France (Princeton, 1939). Cf. A. Monod, De Pascal à Chateaubriand. Les defenseurs francais du Christianisme de I670 à I820 (Paris, I9I6).

I9 I. Berlin, 'The Counter-Enlightenment', in: H. Hardy (ed.), Against the Current. Essays in the History of Ideas (Londen, I979) I.

20 Berlin, 'Counter-Enlightenment', I9. Idem, 'Alleged relativism in eighteenth century European thought', H. Hardy (ed.), The Crooked 
Timber of Humanity. Chapters in the History of Ideas (New York, I990). On Berlin's idea of 'Counter-revolution': R. Wokler, 'Isaiah Berlin's Enlightenment and Counter-Enlightenment', in: J. Mali and R. Wokler (eds), Isaiah Berlin's Counter-Enlightenment (Philadelphia, 2003).

2 I Mali and Wokler, Berlin.

22 M. Lilla, G.B. Vico. The Making of an Anti-Modern (Boston, I993).

23 J. Burson, The Rise and Fall of Theological Enlightenment. Jean-Martin de Prades and Ideological Polarization in Eighteenth Century France (Notre Dame, 20IO).

24 C. Armenteros, The French Idea of History. Joseph de Maistre and His Heirs, I794-I854 (Ithaca, 20I I).

25 D. Masseau, Les Ennemis des philosophes. L'antiphilosophie au temps des Lumieres (Paris, 2000); idem (ed.), Dictionnaire des anti-lumières et antiphilosophes (France, I7I5-I815) (Paris, 2017).

26 D. McMahon, Enemies of the Enlightenment. The French CounterEnlightenment and the Making of Modernity (Oxford, 200I), Io.

27 On the 'Counter-Enlightenment International', see McMahon, Enemies of the Enlightenment, I06-I5 and McMahon, 'Seeing the Century of Lights as a Time of Darkness', Florence Lotterie and Darrin M. McMahon (eds), Les Lumières européennes dans leurs relations avec les autres grandes cultures et religions (Paris, 2002) 8I-IO4, esp. 92-IO3.

28 The Dictionnaire historique edited by François-Xavier de Feller (first of six volumes of the dictionary was first published in I78I) was translated in several languages, including Italian, English and Dutch.

29 A. Sprunck, 'François-Xavier de Feller, I735-I802', J. Mersch (ed.), Biographie nationale du Pays de Luxembourg depuis ses origines jusqu'à nos jours (Luxembourg, I947), 224; M.M. Lok, 'François-Xavier de Feller (I735-I802) et l'élaboration des Contre-Lumières européennes (une reconnaissance)', Rhétorique et politisation contre-révolutionnaire: De la fin des Lumières au printemps des peuples la collection (Rennes, 20I9) (in press).

30 K. Mannheim, 'Conservative thought', From Karl Mannheim, edited by K.H. Wolff (New Brunswick, I993), 260-350.

3 I R. Bourke, Empire and Revolution. The Political Life of Edmund Burke (Princeton, 20I5); W.R.E. Velema, Enlightenment and conservatism in the Dutch Republic. The political thought of Elie Luzac (I72I-I796) (Assen, Maastricht, I993); M.M. Lok, 'Freedom in Counter Revolutionary Thought'. In: A. de Dijn, \& H. Dawson (Eds.), Rethinking Liberty Before Liberalism (Cambridge, in preparation). 
32 Armenteros, French Idea of History.

33 The literature is huge. Fundamental are S.N. Eisenstadt, Comparative Civilizations and Multiple Modernities (2 Vols. Leiden, 2003); J.P. Arnason, S.N. Eisenstadt and B. Wittrock (eds), Axial Civilizations and World History (Leiden, Boston, 2005).

34 Derya Gurses, 'Academic Hutchinsonians and their quest for relevance, I734-I790', History of European Ideas $3 \mathrm{I}$ (2005) 408-27. For a somewhat different take on Hutchinsonianism, see C.D.A. Leighton, 'Hutchinsonianism: A Counter-Enlightenment Reform Movement', The Journal of Religious History 23/2 (I999) I68-84.

35 Michiel Wielema, The March of the Libertines. Spinozists and the Dutch Reformed Church (I660-I750) (Hilversum, 2004).

36 By way of example: Mark S. Morrisson, 'The Periodical Culture of the Occult Revival: Esoteric Wisdom, Modernity and Counter-Public Spheres', Journal of Modern Literature 3I/2, I-22; Joris van Eijnatten, 'Vestige of the Third Force: Willem Bilderdijk, Poet, Anti-Skeptic, Millenarian', Journal of the History of Ideas 62 (200 I), 3 I3-30.

37 H. Hamad and R. Woltering, 'Télémaque, Tahțāwī and the (Counter-) Enlightenment in the Arab world', International Journal for History, Culture and Modernity 6 (20I8); DOI: http://doi.org/I0.I8352/hcm.5I3.

38 Steven Lestition, 'Countering, Transposing, or Negating the Enlightenment? A Response to Robert Norton', Journal of the History of Ideas 68 (2007), 659-8I. The article constitutes a defence of Berlin's interpretation of Herder and Hamann; see also Robert E. Norton, 'The Myth of the CounterEnlightenment', Journal of the History of Ideas, 68 (2007) 635-58.

39 Adam K. Webb, 'The Countermodern Moment: A World-Historical Perspective on the Thought of Rabindranath Tagore, Muhammad Iqbal, and Lian Shuming', Journal of World History I9 (2008), I 89-2 I 2.

\section{About the Authors}

Matthijs Lok (PhD 2009) is lecturer in Modern European History at the University of Amsterdam. Working in the European Studies Department, Lok specializes in the comparative political, cultural and intellectual history of modern Europe since the eighteenth century, with a particular interest in the Restoration era (I8I5-48). He is a founding director of the Amsterdam Seminar for Global Intellectual History. 
His publications include co-edited volumes on Eurocentrism in History and Memory (Amsterdam UP, 20I9) and The Politics of Moderation in Modern European History (Palgrave Series in Political History, 2020). Lok is currently working on book about the 'conservative imagining of Europe in history writing, I780-I850' at the Netherlands Institute for Advanced Study.

Joris van Eijnatten (PhD I993) is professor of cultural history at Utrecht University, the Netherlands. He works on various interrelated subjects, including the history of ideas, religion, media and communication, employing source material from the eighteenth century to the present. His publications include a range of books and articles on toleration, Dutch religious history, the poet Willem Bilderdijk, the Dutch Counter-Enlightenment, sermons, the justification of war, media history and conceptual history. He now specializes in digital history approaches to newspapers, periodicals, parliamentary records and other digitized texts, with a focus on tracing changing concepts over time. $\mathrm{He}$ is a founding editor of the open-access International Journal for History, Culture and Modernity. 